\title{
COMPLEMENTARY DATA ON HAPLOZETES FUSIFER (BERLESE, 1908) (ACARI, ORIBATIDA, HAPLOZETIDAE) COLLECTED FROM IRAN
}

\author{
M. A. Akrami \& M. Behmanesh ${ }^{1}$
}

\section{ABSTRACT}

M. A. Akrami \& M. Behmanesh. 2013. Complementary data on Haplozetes fusifer (Berlese, 1908) (Acari, Oribatida, Haplozetidae) collected from Iran. Graellsia, 69(2): 147-152.

An oribatid mite of the family Haplozetidae, Haplozetes fusifer (Berlese, 1908) is redescribed on the basis of Iranian materials, including the first detailed descriptions of the gnathosoma and legs.

Key words: Oribatid mites; Haplozetidae; Haplozetes fusifer; redescription; morphology.

\section{RESUMEN}

M. A. Akrami \& M. Behmanesh. 2013. Datos adicionales sobre Haplozetes fusifer (Berlese, 1908) (Acari, Oribatida, Haplozetidae) de Irán. Grael/sia, 69(2): 147-152 (en inglés).

Se redescribe un ácaro oribátido de la familia Haplozetidae, Haplozetes fusifer (Berlese, 1908), sobre la base de material iraní, incluyendo las primeras descripciones detalladas del gnatosoma y las patas.

Palabras clave: Ácaros Oribátidos; Haplozetidae; Haplozetes fusifer; redescripción; morfología.

\section{Introduction}

According to the catalogue of Subías (2004, online version 2012), Haplozetidae comprises 19 genera, 11 subgenera, 230 species and 5 subspecies. Within the family, genus Haplozetes is diagnosed by the movable, fully hinged pteromorphs; 10-11 pairs of notogastral setae; four pairs of sacculi; well-developed lamellae, without translamella; well-developed tutoria; four to five pairs of genital setae; mono- or tridactylous legs (Bayartogtokh, 2000).

Haplozetes fusifer (Berlese, 1908) was described as Protoribates (Scheloribates) fusifer from Italy. The original description (Berlese, 1908) of this species was very short and incomplete, lacking figures. Subsequent redescriptions (Schweizer, 1956; Ayyildiz, 1988; Mahunka, 1995) also were

\footnotetext{
Department of Plant Protection, Faculty of Agriculture, Shiraz University, Shiraz, Iran. E-mails: akrami@shirazu.ac.ir; mb_behmanesh@yahoo.com
} 
incomplete (lacking, for example, information about the gnathosoma and legs). Our main objective is to provide a more complete redescription of this species based on Iranian specimens collected during 2009, in the course of a faunistic survey of oribatid mites of Shiraz and Sarvestan cities, Fars province, southern Iran.

\section{Materials and methods}

Soil and litter samples were taken from the surface to a soil depth of $10 \mathrm{~cm}$ under different plants by the junior author. Oribatid mites were extracted in Berlese-Tullgren funnels set over jars of $75 \%$ ethanol. Mites were removed, cleared in lactophenol, and mounted in Hoyer's medium on glass microscope slides. The slides were placed in an oven at $45^{\circ} \mathrm{C}$ for two weeks and then the specimens were examined using a light microscope (Zeiss Standard 20). Figures were made using a drawing tube attached to microscope. Body length was measured from the tip of the rostrum to the posterior edge of the notogaster, and body width refers to the maximum width of the notogaster in dorsal aspect. All body measurements are presented in micrometers $(\mu \mathrm{m})$. In leg formulae, Roman letters refer to normal setae, Greek letters to famulus and solenidia. Single prime (') marks setae on anterior and double prime (") setae on posterior side of the given leg segment and parentheses refer to a pair of setae.

All specimens are deposited in the Acarological collection, Department of Plant Protection, Shiraz University, Shiraz, Iran.

\section{Redescription of species}

\section{Family Haplozetidae Grandjean}

Haplozetes fusifer (Berlese, 1908) (Figs. 1-6)

MATERIAL EXAMINED. Thirteen adults: seven (four females and three males): Ghalat, from soil of azarole trees (Crataegus azarolus L.) and mountain almond (Amygdalus scoparia Spach), 2948'N, 52 $18^{\circ}$ 'E, $2431 \mathrm{~m}$ above sea level, 2 November 2009; four (females): Dasht Arjan, from soil of oak trees (Quercus sp.), 29³4'N, 52॰57'E, $2042 \mathrm{~m}$ above sea level, 2 November 2009, one (female): Sarvestan, from soil of wild cherry (Cerasus sp.), 29 $24^{\prime} \mathrm{N}, 52^{\circ} 47^{\prime} \mathrm{E}, 1600 \mathrm{~m}$ above sea level, 17 December 2009, one (male): Shiraz, from soil of common reed (Phragmites australis (Cav.)), $29^{\circ} 32^{\prime} \mathrm{N}$, $52^{\circ} 35^{\prime} \mathrm{E}, 1810 \mathrm{~m}$ above sea level, 6 August 2009 .
DiAgNOSIS. Body size 405-447 x 263-295; rostrum rounded; lamellae relatively wide, reaching base of rostral setae; interlamellar setae long, reaching anterior end of lamellae; sensilli long, with long and narrow stalk and fusiform-lanceolate head, barbed throughout with short barbs; four pairs of sacculi, with long and narrow canals; 10 pairs of short, slender and smooth notogastral setae; five pairs of sparsely barbulate genital setae; epimeral setae setiform, barbed.

REDESCRIPTION. Integument: Yellowish-brown in color. Cerotegument very thin, with small granules. Integument finely punctate. Surface of notogaster nearly smooth, with numerous small round muscle sigillae anterolaterally and along lateral and posterior margins. Hypostomal surface smooth. Surface of ventral, anal and genital plates nearly smooth.

Measurements: Body length 405-447 (mean 433, nine specimens); body width 263-295 (mean 279, nine specimens). Males and females similar in size.

Prodorsum (Figs. 1, 3). Rostrum broadly rounded anteriorly. Rostral setae (ro, 53-63) fairly long, barbed bilaterally, inserted laterally in front of free tip of the tutorium, extend well beyond tip of rostrum. Lamellae relatively wide, thicker in middle, distinctly narrowed distally, with short cusps, longer than half total length of prodorsum, reaching base of rostral setae. Lamellar setae (le, 67-76) long, conspicuously longer than rostral ones, barbed bilaterally, extending for nearly half of their length beyond the tip of rostrum. Interlamellar setae (in, 53-63) nearly as long as lamellar ones, barbed bilaterally throughout their length, inserted rather far anterior to dorsosejugal suture and close to median margin of lamellae, reaching anterior end of lamellae. Exobothridial setae (ex, 27-32) short, sparsely barbed. Sensilli (ss, 81-92) long, with long and narrow stalk and fusiform-lanceolate head, which is $2 / 3$ as long as the stalk, barbed throughout with short barbs. Bothridium rounded, with wide opening, directed anterolaterally.

Notogaster (Figs. 1, 4). Notogaster wide and round, slightly longer than wide. Anterior notogastral margin convex. Porose areas $A d$ large, wider than long, located posteriorly to alveolus of each interlamellar seta. Pteromorphs well developed, fully hinged, with weakly developed striations radiating from humeral region. 10 pairs of short, slender and smooth notogastral setae with nearly same length (12-17) present. Four pairs of sacculi, clear- 


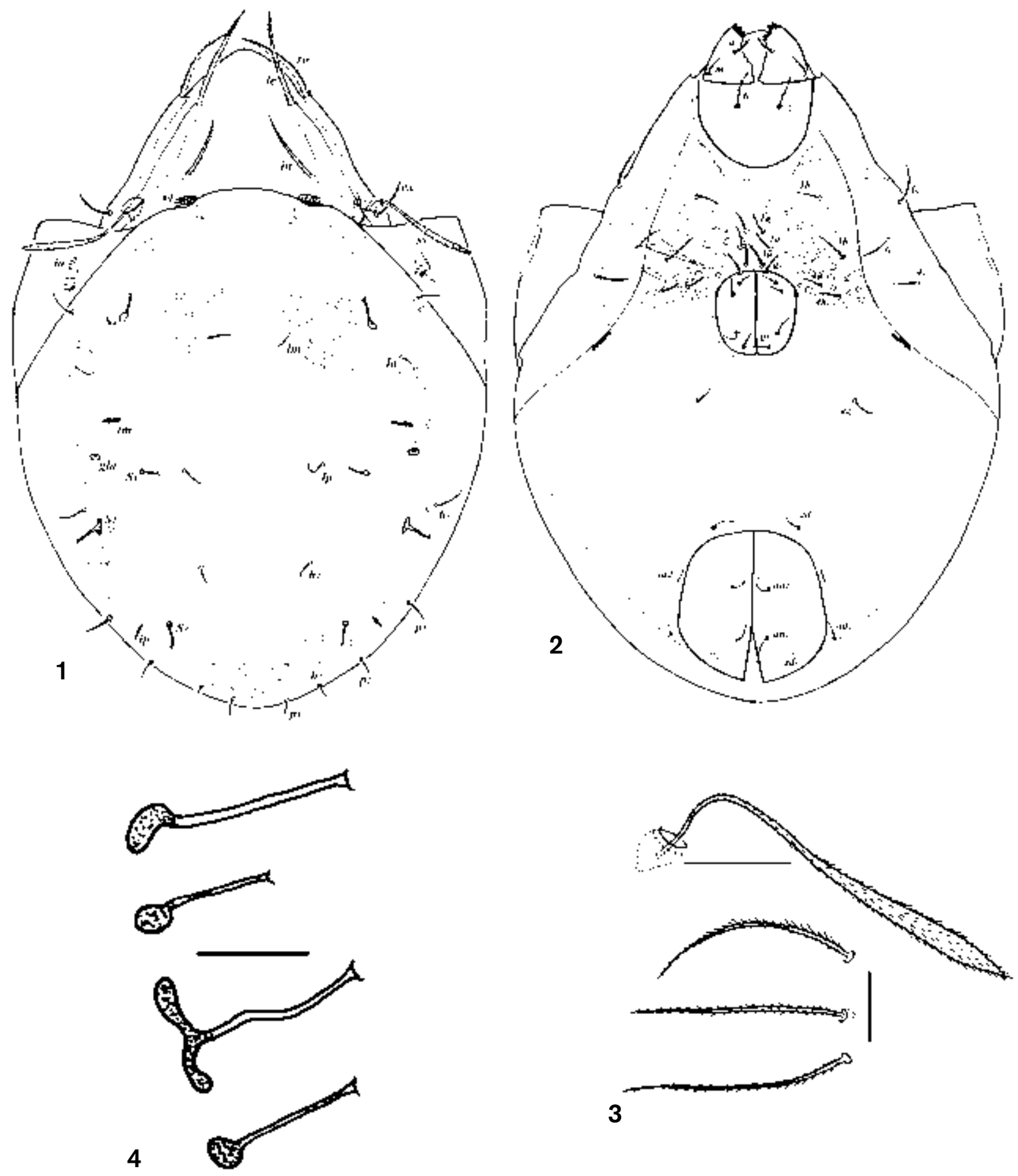

Figs. 1-4.- Haplozetes fusifer. 1) Dorsal view. Scale bar $50 \mu \mathrm{m}$. 2) Ventral view. 3) From top to bottom: sensillus, rostral seta, interlamellar seta and lamellar seta. Scale bar $20 \mu \mathrm{m} .4)$ Sacculi. From top to bottom: $S a, S_{1}, S_{2}$ and $S_{3}$. Scale bar $10 \mu \mathrm{m}$.

Figs. 1-4.- Haplozetes fusifer. 1) Vistas dorsal y 2) ventral, escala $50 \mu \mathrm{m}$. 3) De arriba a abajo: sensilo y setas rostral, interlamelar y lamelar, escala $20 \mu \mathrm{m}$. 4) Sáculos, de arriba a abajo: $S a, S_{1}, S_{2}$ y $S_{3}$, escala $10 \mu \mathrm{m}$. 

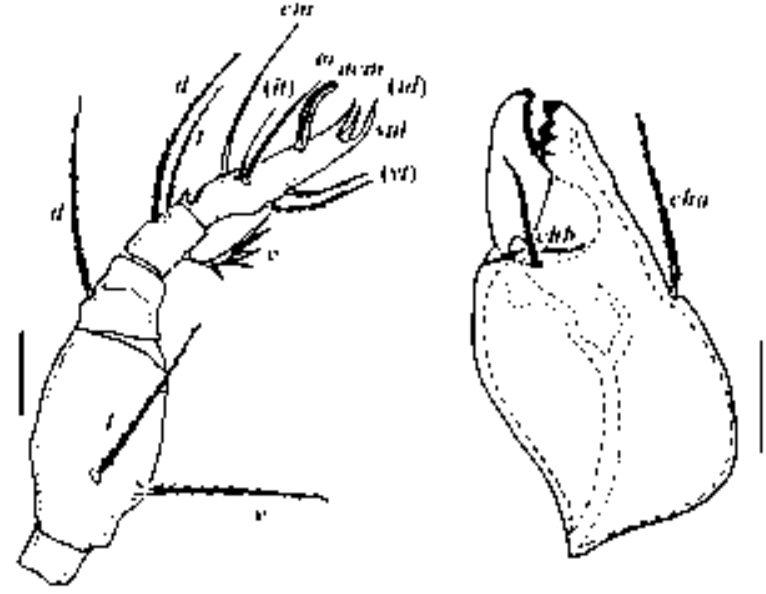

Fig. 5.- Haplozetes fusifer. From right to left: chelicera (Scale bar $20 \mu \mathrm{m}$ ) and palp (Scale bar $10 \mu \mathrm{m}$ ).

Fig. 5.- Haplozetes fusifer. Quelícero (izquierda, escala 20 $\mu \mathrm{m})$ y palpo (derecha, escala $10 \mu \mathrm{m})$.

ly porose and with long and narrow canals, sacculi $S a$ (21) very long, much longer than the others, inserted medially to seta $c, S_{I}(12-13)$ lateral to seta $l p, S_{2}$ (19) bilobed and inserted posteromedially to seta $h_{3}$, and $S_{3}(15)$ rather far posterolaterally to seta $h_{2}$. Lyrifissures $i a, i m$ and $i p$ well developed, $i a$ on pteromorphs and im posteromedial to each seta la. Opisthonotal gland openings ( $\mathrm{gla}$ ) situated posterolaterally to lyrifissures $\mathrm{im}$.

Gnathosoma (Figs. 2, 5). Subcapitulum bearing three pairs of hypostomal setae, all thin and densely barbed; setae $h$ (22) longer than $m$ (17) and $a$ (15). Chelicerae chelate-dentate, with sclerotized teeth, cheliceral setae setiform, barbed, cha (34-35) longer than $\operatorname{chb}(21)$. Palp setation: 0-2-1-3-9(+1 $\omega)$, solenidion $\omega$ and eupathidium acm fused and three other eupathidia $u l$ ', $u l$ " and sul not fused but located very close to each other, all palpal setae barbed, except $\mathrm{cm}$ and (it) on tarsi.

Epimeral region (Fig. 2). With a number of round muscle sigillae. Apodemata apo. 2 and apo.sj well developed, apo.3 short, aligned obliquely, epimeral setae finely barbed bilaterally, $1 c$ (27), $3 b$ (24) and $3 c$ (22) longer than the others (15-19). Setal formula of epimerata: 3-1-3-3.

Anogenital region (Fig. 2). Anal and genital apertures far from each other, former far larger than the latter, interspace between genital and anal opening about twice as long as the length of genital ones. Anogenital region with five pairs of genital setae $\left(g_{1}, 17 ; g_{2}-g_{5}, 12-14\right)$, three arranged on anterior half and the other two on posterior half of the plate, one pair of aggenital (16-17), two pairs of anal (15) and three pairs of adanal (12-14) setae, genital and aggenital setae sparsely barbed, anal and adanal setae smooth. Distance between bases of aggenital setae longer than that between setae $a d_{3}-a d_{3}$. Adanal seta $a d_{1}$ positioned posteriad to anal opening, $a d_{2}$ in adanal position, in posterior angle of the plate and $a d_{3}$ in preanal position, adanal lyrifissure ( $\mathrm{iad}$ ) in adanal position, parallel to lateral margin of the plate, situated almost midway between setae $a d_{2}$ and $a d_{3}$.

Legs (Fig. 6). All tarsi heterotridactylous, with lateral claws much thinner than empodial claw. Femora II and IV with large, distally rounded ventral keels. Femora I-IV and trochanters III-IV with large porose areas. All leg setae distinctly barbed. On tarsi I solenidion $\omega_{1}$ much longer and more slender than $\omega_{2}$; famulus $\varepsilon$ short, straight, bluntended, situated behind $\omega_{l}$. Tibiae I with extremely

Table 1.- Leg setation and solenidia of adult Haplozetes fusifer.

Tabla 1.- Setación de las patas y del solenidio en adultos de Haplozetes fusifer.

\begin{tabular}{ccccll}
\hline Leg & Trochanter & Femur & Genu & Tibia & \multicolumn{1}{c}{ Tarsus } \\
\hline I & $v^{\prime}$ & $d,(I), b v^{\prime \prime}, v^{\prime \prime}$ & $(I), v^{\prime}, \sigma$ & $(I),(v), \varphi_{1}, \varphi_{2}$ & $(f t),(t c),(i t),(p),(u),(a), s,(p v), v^{\prime},(p l), \varepsilon, \omega_{1}, \omega_{2}$ \\
II & $v^{\prime}$ & $d,(I), b v^{\prime \prime}, v^{\prime \prime}$ & $(I), \sigma$ & $(l),(v), \varphi$ & $(f t),(t c),(i t),(p),(u),(a), s,(p v), \omega_{1}, \omega_{2}$ \\
III & $l^{\prime}, v^{\prime}$ & $d, l^{\prime}, e v^{\prime}$ & $l^{\prime}, \sigma$ & $l^{\prime},(v), \varphi$ & $(f t),(t c),(i t),(p),(u),(a), s,(p v)$ \\
IV & $v^{\prime}$ & $d, e v^{\prime}$ & $d, l^{\prime}$ & $l^{\prime},(v), \varphi$ & $f t^{\prime \prime},(t c),(p),(u),(a), s,(p v)$ \\
\hline
\end{tabular}



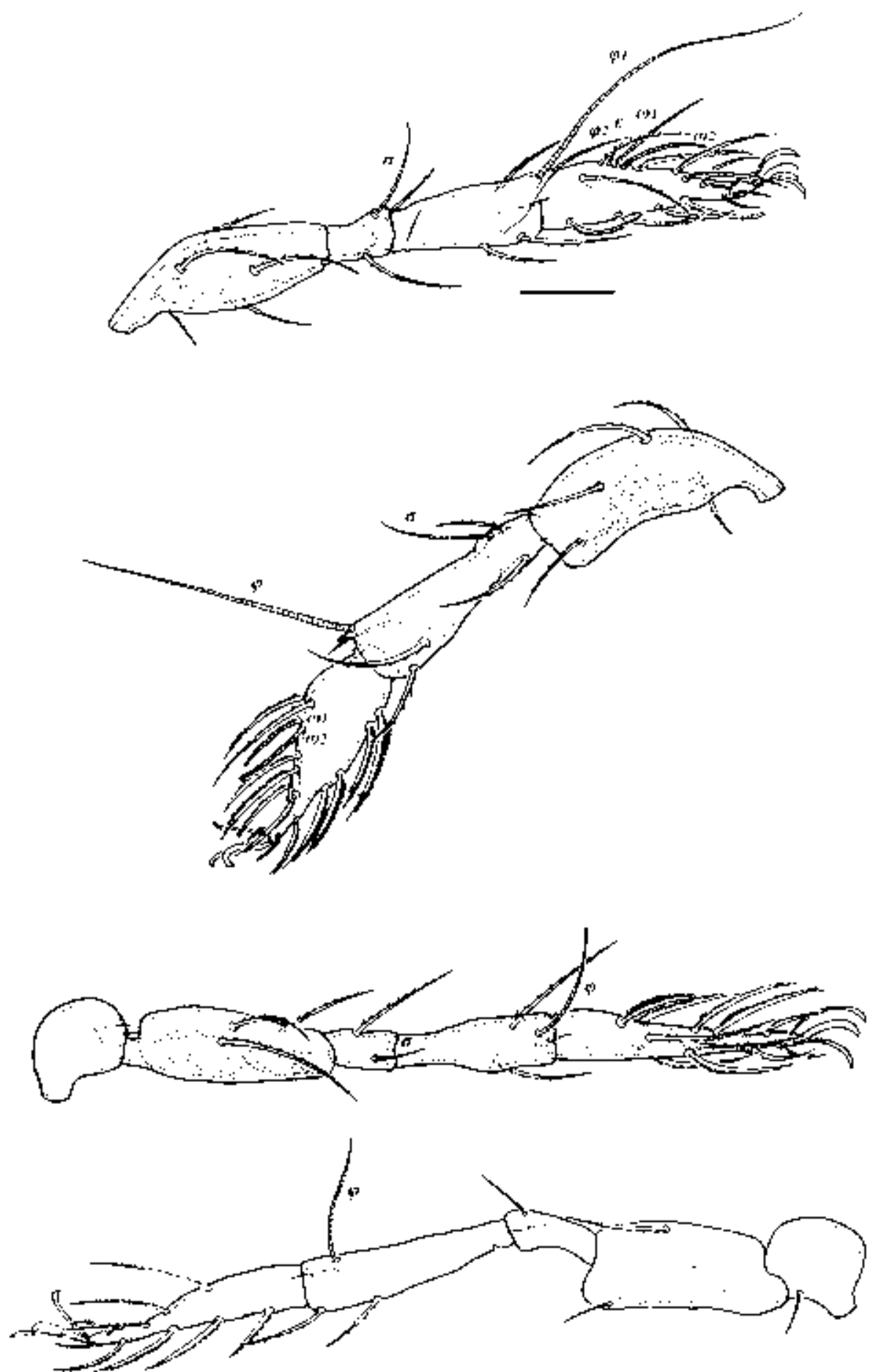

Fig. 6.- Haplozetes fusifer. Legs. From top to bottom: leg I, II, III and IV. Scale bar $25 \mu \mathrm{m}$.

Fig. 6.- Haplozetes fusifer. Patas I, II, III y IV, de arriba a abajo. Escala $25 \mu \mathrm{m}$. 
Table 2.- Variability of some morphological characters in adult Haplozetes fusifer.

Table 2.- Variabilidad de caracteres morfológicos en adultos de Haplozetes fusifer.

\begin{tabular}{|c|c|c|c|c|c|c|}
\hline Literature data from & Our data & $\begin{array}{r}\text { Berlese } \\
(1908)\end{array}$ & $\begin{array}{l}\text { Schweizer } \\
\text { (1956) }\end{array}$ & $\begin{array}{l}\text { Ayyildiz } \\
\text { (1988) }\end{array}$ & $\begin{array}{c}\text { Mahunka } \\
(1995)\end{array}$ & $\begin{array}{c}\text { Pérez-Iñigo \& Peña } \\
\text { (1996) }\end{array}$ \\
\hline \multicolumn{7}{|l|}{ Character } \\
\hline Body length & $405-447$ & 500 & 540 & 504 & Data absent & $463-498$ \\
\hline Body width & $263-295$ & 390 & 315 & 216 & Data absent & $285-338$ \\
\hline Length of sensilli & Long* & Long & Short ${ }^{\star \star}$ & Short & Long & Long \\
\hline $\begin{array}{l}\text { Length of interlamellar } \\
\text { setae }\end{array}$ & $\begin{array}{l}\text { Reaching anterior } \\
\text { end of lamellae }\end{array}$ & Data absent & $\begin{array}{l}\text { Very long } \\
\text { (exceed from } \\
\text { rostral tip) }\end{array}$ & $\begin{array}{l}\text { Exceed from } \\
\text { base of } \\
\text { lamellar } \\
\text { setae }\end{array}$ & $\begin{array}{l}\text { Exceed from } \\
\text { base of } \\
\text { lamellar } \\
\text { setae }\end{array}$ & $\begin{array}{l}\text { exceed from base of } \\
\text { lamellar setae }\end{array}$ \\
\hline
\end{tabular}

* exceed from margin of pteromorphs

** not exceed from margin of pteromorphs

long and thick solenidion $\varphi_{1}$, and a short and thin $\varphi_{2}$ inserted on projected apophysis. Genua I with long solenidion $\sigma$. On tarsi II solenidion $\omega_{1}$ slightly shorter than $\omega_{2}$; Anterodorsal end of tibiae II with a short but sharply pointed projection. Formula of leg setation (including famulus): I (1-5-3-4-19); II (15-2-4-15); III (2-3-1-3-15); IV (1-2-2-3-12); the formula of solenidia: I (1-2-2); II (1-1-2); III (1-1$0)$; IV (0-1-0). Homology of setae and solenidia indicated in Table 1.

REMARKS. Some morphological characters of Haplozetes fusifer are variable (body size, length of sensilli and interlamellar setae) in specimens from different regions (Italy, Germany, Turkey) (Berlese 1908; Schweizer 1956; Ayyildiz 1988). A comparison of these differences is presented in Table 2.

\section{Acknowledgements}

This study was partly supported by the project "Fauna of oribatid mites of Shiraz, Fars province" funded by Shiraz University.

\section{References}

Ayyildiz, N., 1988. [Three new Scheloribates Berlese species (Acari: Scheloribatidae) for the Turkish fauna.] Türkiye Entomoloji Dergisi, 12: 171-177 (in Turkish).

Bayartogtokh, B., 2000. Three species of Haplozetes (Acari: Oribatida: Haplozetidae) from Mongolia. International Journal of Acarology, 26: 11-24.
Berlese, A., 1908. Elenco di generi e specie nuove di Acari. Redia, 5: 1-15.

Grandjean, F., 1936. Observations sur les Oribates $\left(10^{\mathrm{e}}\right.$ série). Bulletin du Muséum d'Histoire Naturelle, Paris, 2: 246-253.

Mahunka, S. \& Mahunka-Papp, L., 1995. The oribatid species described by Berlese (Acari). Hungarian Natural History Museum. Budapest 325 pp.

Pérez-Iñigo, C. \& Peña, M. A., 1996. Oribátidos edáficos (Acari, Oribatei) de Gran Canaria. II. Boletín de la Asociación Española de Entomología, 20: 201219.

Schweizer, J., 1956. Die Landmilben des schweizerischen Nationalparkes 3. Teil: Sarcoptiformes Reuter 1909. Ergebnisse der Wissenschaftlichen Untersuchungen des Schweizerischen Nationalparks, 5(34): 215-377.

Subías, L. S., 2004. Listado sistemático, sinonímico y biogeográfico de los ácaros oribátidos (Acariformes: Oribatida) del mundo (excepto fósiles). Graellsia, 60(número extraordinario): 3-305. Online version accessed in April 2012. (http://www.ucm.es/info/ zoo/Artropodos/Catalogo.pdf)

Willmann, C., 1935. Faunistisch-ökologische Studien im Anningergebeit. IV. Die Milbenfauna. 1. Oribatei. Zoologische Jahrbücher. Abteilung für Systematik, 66: 331-344. 